\title{
Effect of steam-cooking on (poly)phenolic compounds in purple yam and purple sweet potato tubers
}

\author{
${ }^{1}$ Cakrawati, D., ${ }^{1}$ Srivichai, S. and ${ }^{1,2, *}$ Hongsprabhas, P. \\ ${ }^{1}$ Department of Food Science and Technology, Faculty of Agro-Industry, Kasetsart University, Chatuchak, \\ Bangkok 10900, Thailand \\ ${ }^{2}$ Center of Excellence on Agricultural Biotechnology: (AG-BIO/PERDO-CHE), Bangkok 10900, Thailand
}

\author{
Article history: \\ Received: 29 July 2020 \\ Received in revised form: 25 \\ August 2020 \\ Accepted: 27 September \\ 2020 \\ Available Online: 24 January \\ 2021
}

\section{Keywords:}

Alatanin,

Anthocyanin,

Antioxidant,

Sweet potato,

Yam

DOI:

https://doi.org/10.26656/fr.2017.5(1).407

\begin{abstract}
This study investigated the influences of steam-cooking on (poly)phenolic compounds and colors in purple yam (Dioscorea alata L.) and purple sweet potato (Ipomoea batatas) tubers cooked at the household level. Steam-cooking did not significantly change the contents of total phenolic compounds, flavonoids, anthocyanins and antioxidant capacity measured by ABTS radical scavenging assay in purple yam $(P \geq 0.05)$, but lowered the antioxidant capacity measured by Crocin assay $(P<0.05)$. The liquid chromatographmass spectrometer-Ion Trap-Time of Flight (LCMS-IT-TOF) indicated the degradation of high MW alatanin B to lower MW alatanins due to the loss of glucose units. Purple sweet potato, however, responded to steam-cooking differently from purple yam $(P<0.05)$. Steam-cooking drastically increased total phenolic compounds, flavonoids, anthocyanins, antioxidant capacities, and retained the vivid reddish-purple color of cooked purple sweet potato $(P<0.05)$. The stability of polyphenolic compounds in starchy tubers against steam-cooking at the household level was, in part, due to the different contents of indigenous phenolic compounds in the raw tubers.
\end{abstract}

\section{Introduction}

Tuber crops are an essential carbohydrate source in tropical and subtropical countries. Sweet potato (Ipomoea batatas) is the second-largest tuber production in the world, followed by yam (Dioscorea alata L.) (Lebot, 2020). Numerous studies have shown that yam and sweet potatoes are a good source of essential nutrients and bioactive compounds (Kano et al., 2005; Christina and Rifa'i, 2014; Lebot, 2020). Isoprenoids and (poly)phenolic compounds in tuber crops have received much attention during recent decades for their potential effects on human health, particularly in neurodegenerative diseases, inflammation, cancer, cardiovascular health, type 2 diabetes, obesity, and interactions with gut microbiota (Cory et al., 2018) due to their antioxidant capacities (Cornago et al., 2011).

At the cellular level, phenolic and polyphenolic compounds stored in the vacuole. During cooking, the interactions among these bioactive compounds and other nutrients, particularly protein, could affect their bioavailability. Therefore, it is essential to understand the effect of cooking, even at typical culinary preparation, on the changes of (poly)phenolic compounds in order to preserve the contents or prevent the loss of these compounds.

Anthocyanins in purple yam and purple sweet potato can be classified into non-acylated, mono-acylated, and di-acylated with $p$-hydroxybenzoic, ferulic, or caffeic acid as acyl group. Cyanidin-3-caffeoyl- $p$ hydroxybenzoylsophoroside-5-glucoside and peonidin 3caffeoyl-p-hydroxybenzoylsophoroside-5-glucoside were two dominant di-acylated anthocyanins in purple sweet potato (Truong et al., 2010; de Aguiar Cipriano et al., 2015; Hong and Koh, 2016; Chen et al., 2017). While, predominant anthocyanin in purple yam is cyanidin 3-(6sinapoylgentiobioside) (Moriya et al., 2015). Although the aglycone in anthocyanins of both plants is cyanidin nucleus, the glycosides and acyl groups vary considerably. The anthocyanins from different plants could give different responses to external factors such as $\mathrm{pH}$, heat, light, and $\mathrm{O}_{2}$. Tsukui (1988) reported that the purified anthocyanins from $u b e$ yam were the most heatstable anthocyanin compared to the anthocyanins from purple corn, purple sweet potato, red cabbage, and grape.

Nonetheless, the responses of anthocyanins to heat in gelatinized starchy matrices could be different and varied 
considerably depending on plant compositions. Steed and Truong (2008) reported that steaming of purple sweet potato did not change the total phenolic content but decreased monomeric anthocyanin in the methanol $(\mathrm{MeOH})$ extract, reported as cyanidin 3-glucoside $(\mathrm{C} 3 \mathrm{G})$ from 269 to $220.34 \mathrm{mg} \mathrm{C} 3 \mathrm{G} / 100 \mathrm{~g}$ dry basis (d.b.). However, Chen et al. (2017) reported that steaming increased the anthocyanin content in the $\mathrm{MeOH}$ extract of purple sweet potato from 455.08 to $503.63 \mathrm{mg}$ C3G/100 g d.b. Besides, steaming of purple yam increased phenolic contents from 85.36 to $167.22 \mathrm{mg}$ GAE/100 g d.b. and raised anthocyanin level from 36.09 to $57.28 \mathrm{mg} \mathrm{C} 3 \mathrm{G} / 100 \mathrm{~g}$ d.b. as reported by Imanningsih et al. (2013).

The objective of this study was to further explore the influences of steam-cooking at the household level typically used to gelatinize tuber starch for direct consumption on the changes in (poly)phenolic compounds, including anthocyanins, as well as the antioxidant capacities and colors in purple yam and purple sweet potato. The alterations of these bioactive compounds may affect their availabilities in the cooked starchy tubers readily for consumption.

\section{Materials and methods}

\subsection{Sample preparation}

Purple sweet potato of unknown cultivar was purchased from a local market Talad Thai, Pathum Thani province, Thailand. The purple yam accession KKFCRC (Khon Kaen Field Crop Research Center, Department of Agriculture, Ministry of Agriculture and Co-operatives, Thailand) was supplied by the farmers in Phra Nakhon Si Ayutthaya province, Thailand. The sweet potato and yam tubers were cleaned with tap water and sliced to $5 \times 3 \times 1$ $\mathrm{cm}$, ground using a coconut shredder, and dried in a hot air oven at $40^{\circ} \mathrm{C}$ for $24 \mathrm{hrs}$ to reduce moisture to 10 $11 \%$. The dried sample was ground and sieved through a 100 -mesh screen, designated as flour from raw tubers. Purple yam tubers with $8 \mathrm{~cm}$ in diameter and $22 \mathrm{~cm}$ in length were cut into half and steam-cooked in a homecooker on a gas stove for $60 \mathrm{mins}$ to gelatinize yam starch to the level of direct consumption. Purple sweet potato tubers with a diameter of $5 \mathrm{~cm}$ and a length of 13 $\mathrm{cm}$ were cut into half and steam-cooked in a homecooker for 30 mins. The different cooking regimes for purple yam and purple sweet potato tubers were to follow a common household cooking practice for ingestion. Prolonging the cooking time for sweet potato resulted in the soggy texture and the loss of purple pigment to the drips. After the cooked sample cooled down to room temperature, it was ground and dried to 10 $-11 \%$ moisture content in an oven at $40^{\circ} \mathrm{C}$ for $24 \mathrm{hrs}$. All samples were kept in a sealed plastic bag placed inside the sealed aluminum foil at $-18^{\circ} \mathrm{C}$ before analysis.

\subsection{Evaluation}

Approximately, $1 \mathrm{~g}$ of sample was added with $10 \mathrm{~mL}$ of $50 \%$ ethanol (EtOH) acidified with $0.1 \% \mathrm{HCl}$ to $\mathrm{pH} 2$. The mixture was stirred at $50^{\circ} \mathrm{C}$ for 60 mins in a waterbath shaker (PR-100, Eyela, Bunkyo-ku, Tokyo, Japan) and centrifuged at $3400 \times g$ for 10 mins using an Ohaus benchtop centrifuge (Frontier ${ }^{\mathrm{TM}} 5000$, Ohaus, Melbourne, Victoria, Australia). The supernatant was filtered through a Whatman no. 1 filter paper. The filtrate was evaporated in a vacuum evaporator centrifuge (CentriVap Benchtop Centrifugal Vacuum Concentrator, Labconco, Kansas City, Missouri, USA) at $40^{\circ} \mathrm{C}$. The extract was re-diluted with $5 \mathrm{~mL}$ of $50 \%$ acidified $\mathrm{EtOH}$, filtered through the Whatman syringe filter $0.45 \mu \mathrm{m}$ pore size (GE Healthcare UK Limited, Little Chalfont, Buckinghamshire, UK) for analyses as follows:

\subsubsection{Total phenolic content}

The extract $(0.1 \mathrm{~mL})$ was added with $0.1 \mathrm{~mL}$ of Folin-Ciocalteau reagent. The mixture was allowed to react for 6 mins. Then, it was added with $1 \mathrm{~mL}$ of $7 \%$ $\mathrm{NaCO}_{3}$ and $1 \mathrm{~mL}$ of distilled water (Dewanto et al., 2002). After 90 mins of reaction, the absorbance was measured at $760 \mathrm{~nm}$ using a Genesys $10 \mathrm{UV}$ spectrophotometer (Thermo Fischer Scientific, Waltham, Massachusetts, USA). The phenolic content was calculated using a standard curve of gallic acid and expressed as mg gallic acid equivalent (GAE) in $100 \mathrm{~g}$ of flour on a dried weight basis (mg GAE/100 g flour).

\subsubsection{Total flavonoid content}

The extract of $0.25 \mathrm{~mL}$ was mixed with $1.25 \mathrm{~mL}$ of distilled water and $0.075 \mathrm{~mL}$ of $5 \% \mathrm{NaNO}_{2}$ solution and allowed to react for 5 mins. The mixture was added with $0.15 \mathrm{~mL}$ of $10 \%$ aluminum chloride solution; the reaction was allowed to proceed for 6 mins, followed by the addition of $0.5 \mathrm{~mL} 1 \mathrm{M} \mathrm{NaOH}$. Distilled water was added to bring the final volume to $3 \mathrm{~mL}$ (Yang et al., 2004). The absorbance was measured at $510 \mathrm{~nm}$ using a Genesys 10 UV spectrophotometer. The flavonoid content was determined using a catechin standard curve and expressed as $\mathrm{mg}$ catechin equivalent (CE) in $100 \mathrm{~g}$ of flour on a dried weight basis (mg CE/100 $\mathrm{g}$ flour).

\subsubsection{Monomeric anthocyanin}

Monomeric anthocyanin in the extract was determined using a $\mathrm{pH}$-differential method described by Lee et al. (2005). Two buffer systems: $0.025 \mathrm{M}$ potassium chloride buffer, $\mathrm{pH} 1.0$ and $0.4 \mathrm{M}$ sodium acetate buffer, $\mathrm{pH} 4.5$, were used. The absorbance was 
read at $510 \mathrm{~nm}$ and $700 \mathrm{~nm}$ using a Genesys $10 \mathrm{UV}$ spectrophotometer. Total monomeric anthocyanin content was calculated and reported as mg cyanidin-3glucoside in $100 \mathrm{~g}$ of flour on a dried weight basis (mg $\mathrm{C} 3 \mathrm{G} / 100 \mathrm{~g}$ flour).

\subsubsection{Antioxidant capacities}

\subsubsection{Trolox equivalent antioxidant capacity (TEAC) assay}

The ABTS radical scavenging assay was based on electron transfer (ET) mechanism (Re et al., 1999; Huang et al., 2005). The $\mathrm{ABTS}^{\circ+}$ was generated by mixing $5 \mathrm{~mL}$ of $7 \mathrm{mM}$ ABTS with $88 \mu \mathrm{L}$ of $140 \mathrm{mM}$ $\mathrm{K}_{2} \mathrm{~S}_{2} \mathrm{O}_{8}$ in the dark and held for $24 \mathrm{hrs}$ at room temperature before use. The $\mathrm{ABTS}^{*+}$ stock solution was diluted to get an absorbance of 0.700 at $734 \mathrm{~nm}$ in phosphate buffer saline (PBS) assessed by a Genesys 10 UV spectrophotometer. A volume of $5 \mu \mathrm{L}$ of diluted sample was mixed with $1 \mathrm{~mL}$ of $\mathrm{ABTS}^{\circ+}$ radical solution. The decolorization of the $\mathrm{ABTS}^{\circ+}$ at $734 \mathrm{~nm}$ after 4 mins at $30^{\circ} \mathrm{C}$ using PBS as a control was evaluated by measuring the absorbance at $734 \mathrm{~nm}$ using a Genesys 10 UV spectrophotometer. The ET antioxidant capacity of the extract was reported as $\mu$ mol Trolox equivalent (TE)/ $\mathrm{g}$ flour on a dried weight basis.

\subsubsection{Crocin assay}

The Crocin bleaching assay (CBA) described by Tubaro et al. (1998) and Di Majo et al. (2008) was used to evaluate the antioxidant activity of the extract based on the hydrogen atom transfer (HAT) mechanism (Huang et al., 2005). The assay was based on the comparison of Crocin bleaching rates in the absence and presence of the antioxidant. The standard antioxidant Trolox $(0.1-1 \mathrm{mM})$ was used to quantify the EtOH extract's antioxidant capacity determined from the plot between relative bleaching rate and Trolox concentration. The extract's antioxidant capacity was expressed as $\mu \mathrm{mol}$ Trolox equivalent (TE)/g flour on a dried weight basis.

\subsubsection{Identification of anthocyanin of purple yam by liquid chromatography-mass spectrophotometry}

Anthocyanins in the EtOH extract from flour prepared from a raw yam tuber and steam-cooked tuber were characterized by LCMS-IT-TOF (SHIMADZU, Chiyoda-ku, Tokyo, Japan) coupled with Prevail ${ }^{\mathrm{TM}} \mathrm{C} 18$ column $(5 \mu \mathrm{m}, 150 \times 4.6 \mathrm{~mm})$ as described previously (Srivichai and Hongsprabhas, 2020). Mass spectrometry parameters (MS) were operated using a capillary voltage of $4.5 \mathrm{kV}$, interface temperature $200^{\circ} \mathrm{C}$, heat block temperature $200^{\circ} \mathrm{C}$, and $\mathrm{N}_{2}$ gas flow of $1.5 \mathrm{~L} / \mathrm{min}$. The instrument was operated in a positive ion mode, scanning from $\mathrm{m} / \mathrm{z} 100$ to 2500, collision gas (argon) pressure at
$50 \%$, and collision energy at $50 \%$.

\subsection{Statistical analysis}

The experiment was carried out using a completely block randomized design with two independent replications. The data were analyzed by analysis of variance (ANOVA) at a 95\% significance level, followed by Duncan's multiple range tests (DMRT) for post hoc analysis using SPSS software version 12 (SPSS Inc., USA).

\section{Results and discussion}

The KKFCRC purple yam flesh (Figure 1) had a vivid purple color, although the purple pigment did not distribute evenly within the whole tuber. The purple pigment retained after drying the raw tubers at $40^{\circ} \mathrm{C}$ for $24 \mathrm{hrs}$ (Figure 1C), suggesting that yam purple pigment in raw tuber was quite stable to drying in a hot air oven at $40^{\circ} \mathrm{C}$ for $24 \mathrm{hrs}$.
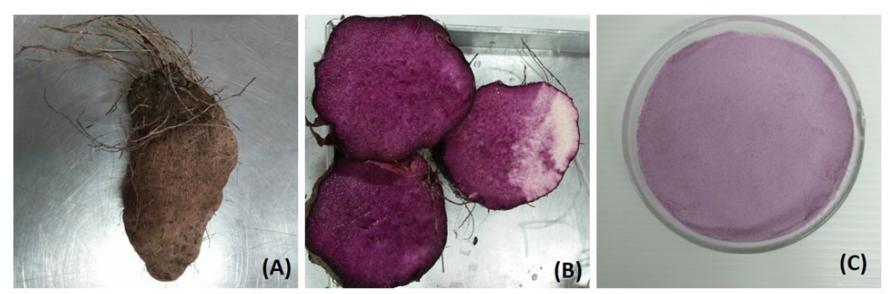

Figure 1. The appearance of (A) KKFCRC yam tuber, (B) yam flesh, and (C) yam flour made from a raw tuber

The contents of phenolic and (poly)phenolic compounds, namely flavonoids and anthocyanins, in $\mathrm{EtOH}$ extract of purple yam shown in Figure 2A suggested that steam-cooking did not affect the contents of these compounds $(P \geq 0.05)$. This result was in agreement with Cornago et al. (2011), who reported that heating did not affect (poly)phenolic compounds in purple yam. However, Figures 2B and 2C illustrate slightly different profiles of anthocyanins in raw and steamed-cooked purple yam. The major anthocyanins in KKFCRC yam in Thailand have been reported earlier as the alatanin B (peak 5) and alatanin C (peak 6) isomers, which had molecular ion precursor $[\mathrm{M}]^{+}(\mathrm{m} / \mathrm{z})$ at 1347 and 817, respectively (Srivichai and Hongsprabhas, 2020). Both alatanins were also predominant in the Philippine ube yam (Yoshida et al., 1991).

Both raw and steam-cooked yam contained anthocyanins identified as summarized in Table 1. Although steam-cooking did not affect total monomeric anthocyanin, it changed the anthocyanin profile quantitatively evaluated as the area under the curve (AUC). The AUC of alatanin C (peak 6), the major anthocyanin in raw KKFCRC tubers and steam-cooked 
Table 1. Effect of steam-cooking at household level on anthocyanin profiles of EtOH extracts from flour prepared from the raw and cooked yam tubers

\begin{tabular}{cccccccccc}
\hline $\begin{array}{c}\text { Peak } \\
\text { number time (min) }\end{array}$ & $\begin{array}{c}\text { Retention } \\
\text { identification* }\end{array}$ & $\begin{array}{c}\text { Molecule } \\
\text { structure }\end{array}$ & $\begin{array}{c}\text { Molecular ion } \\
\text { precursor }[\mathrm{M}]^{+} \\
(\mathrm{m} / \mathrm{z})\end{array}$ & $\begin{array}{c}\text { Anthocyan } \\
\text { idin unit }\end{array}$ & $\begin{array}{c}\text { Sugar } \\
\text { unit(s) }\end{array}$ & $\begin{array}{c}\text { Acyl } \\
\text { unit (s) }\end{array}$ & $\begin{array}{c}\text { The ratio of AUC } \\
\text { Raw tuber }\end{array}$ \\
\hline 3 & 40.28 & $\begin{array}{c}\text { Cyanidin 3- } \\
\text { gentiobioside }\end{array}$ & $\mathrm{C}_{27} \mathrm{H}_{31} \mathrm{O}_{16}$ & 611 & Cyanidin & 2 glucose & - & $0.046^{\mathrm{b}}$ & $0.270^{\mathrm{a}}$ \\
4 & 41.36 & Alatanin E & $\mathrm{C}_{44} \mathrm{H}_{51} \mathrm{O}_{25}$ & 979 & Cyanidin & 3 glucose & 1 sinapoyl & $0.395^{\mathrm{b}}$ & $0.594^{\mathrm{a}}$ \\
5 & 41.74 & Alatanin B & $\mathrm{C}_{61} \mathrm{H}_{71} \mathrm{O}_{34}$ & 1347 & Cyanidin & 4 glucose & 2 sinapoyl & $0.682^{\mathrm{a}}$ & $0.525^{\mathrm{b}}$ \\
6 & 42.84 & Alatanin $\mathrm{C}$ & $\mathrm{C}_{38} \mathrm{H}_{41} \mathrm{O}_{20}$ & 817 & Cyanidin & 2 glucose & 1 sinapoyl & $1.000^{\mathrm{a}}$ & $1.000^{\mathrm{a}}$ \\
7 & 43.43 & Alatanin $\mathrm{G}$ & $\mathrm{C}_{37} \mathrm{H}_{39} \mathrm{O}_{19}$ & 787 & Cyanidin & 2 glucose & 1 feruloyl & $0.172^{\mathrm{a}}$ & $0.176^{\mathrm{a}}$ \\
8 & 43.63 & Alatanin $\mathrm{D}$ & $\mathrm{C}_{55} \mathrm{H}_{61} \mathrm{O}_{29}$ & 1185 & Cyanidin & 3 glucose & 2 sinapoyl & $0.100^{\mathrm{b}}$ & $0.175^{\mathrm{a}}$ \\
9 & 44.44 & Alatanin $\mathrm{F}$ & $\mathrm{C}_{39} \mathrm{H}_{43} \mathrm{O}_{20}$ & 831 & Peonidin & 2 glucose & 1 sinapoyl & $0.064^{\mathrm{a}}$ & $0.045^{\mathrm{a}}$ \\
\hline
\end{tabular}

Different letters in the same row indicate significant differences based on paired t-test $(P<0.05)$.

* Tentative identification for KKFCRC purple yam was previously reported by Srivichai and Hongsprabhas (2020)
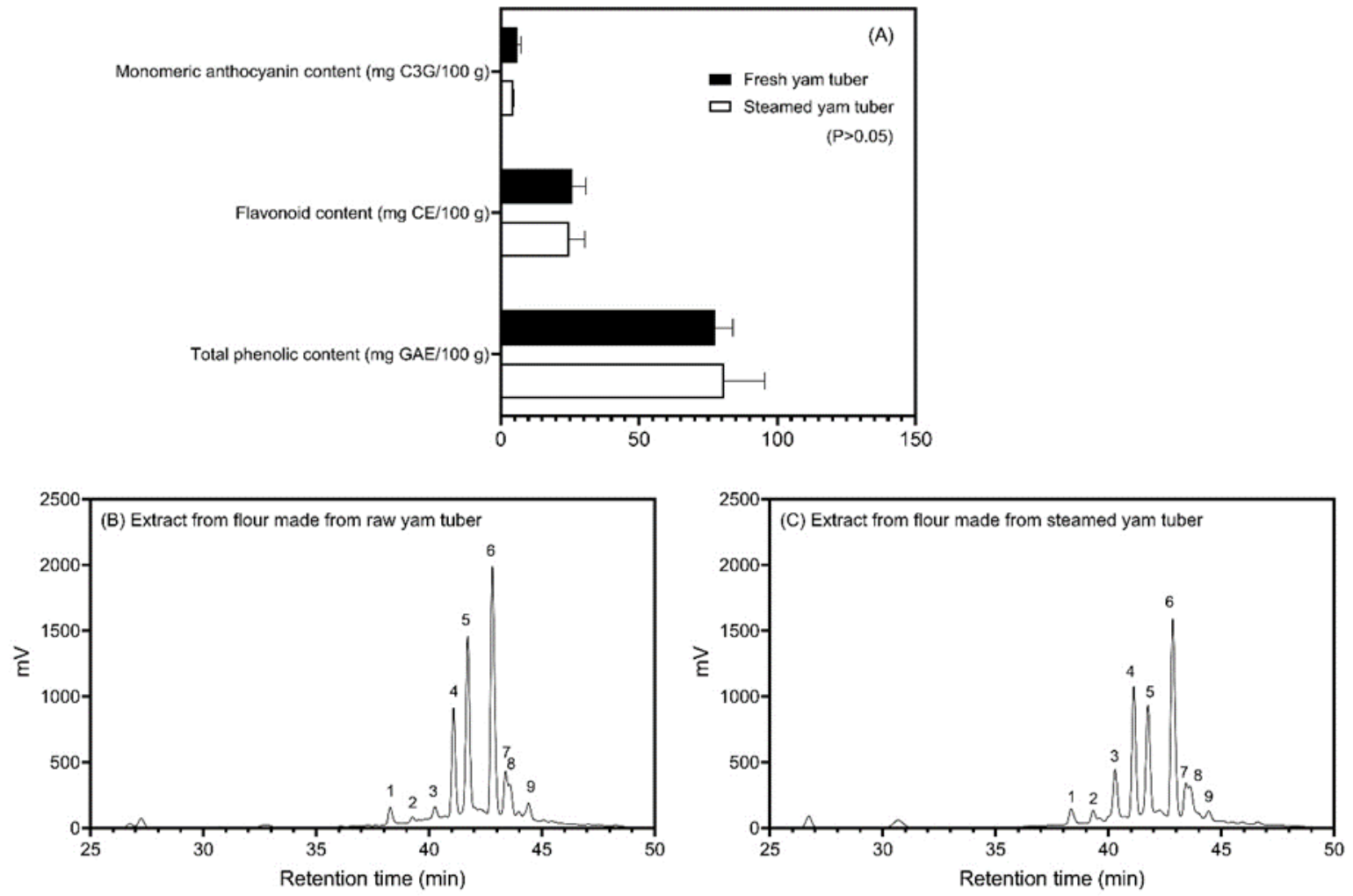

Figure 2. (A) The content of (poly)phenolic compounds in raw and steam-cooked purple yam in EtOH extract, (B) LC-MS/MS chromatograms of raw purple yam and (C) of steam-cooked purple yam. Peak numbers refer to Table 1

ones, was used as the reference anthocyanin for comparison within the same treatment, i.e., raw or steamcooked yam tuber. The relative ratio of each isomer (compared to alatanin C) was subjected to a paired $t$-test to assess the influence of steam-cooking on the isomers compared to the raw one. Table 1 shows that alatanin B (peak 5), which had the highest MW, decreased, while the smaller MW cyanidin-3 gentiobioside (peak 3), alatanin E (peak 4), and alatanin D (peak 8) increased after steam-cooking. The relative increase in smaller MW anthocyanins in KKFCRC yam tuber may be due to the loss of glucose units, which agreed with the report on alatanin B degradation to cyanidin-3 gentiobioside after steam-cooking investigated by Sadilova et al. (2006).

However, the influences of steam-cooking on the antioxidant capacities of purple sweet potato were different from purple yam (Figure 3). EtOH extract from raw purple sweet potato had a higher antioxidant capacity measured by TEAC assay than raw purple yam (Figure 3A). Steam-cooking drastically increased the antioxidant capacity of purple sweet potato based on ET mechanism $(P<0.05)$ but did not affect the ET-based antioxidant capacity of purple yam $(P \geq 0.05)$. Crocin assay, which determined antioxidant capacity based on HAT mechanism, indicated that steam-cooking did not affect the antioxidant capacity of purple sweet potato but 
lowered that of purple yam $(\mathrm{P}<0.05)$.

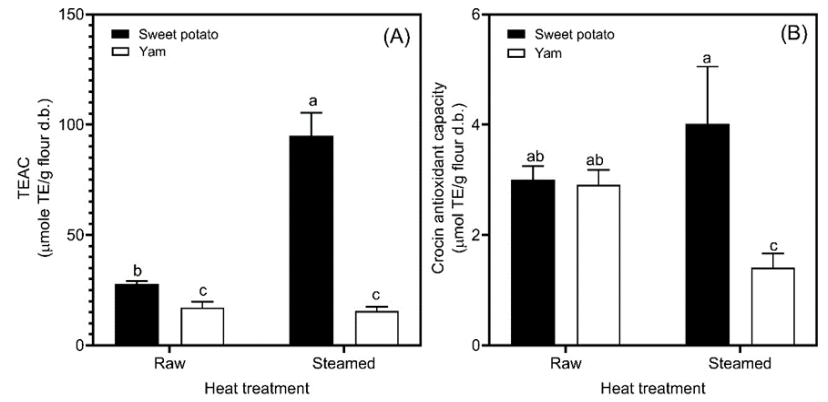

Figure 3. Effect of steam-cooking at household level on antioxidant capacities of purple sweet potato and purple yam: (A) electron transfer mechanism measured by TEAC (ABTS radical scavenging capacity); (B) hydrogen atom transfer mechanism measured by Crocin assay. Bars represent standard deviation

The flour prepared from raw purple sweet potato showed brown color, while the flour made from steamcooked purple sweet potato showed reddish-purple color (Figure 4). Moreover, steam-cooking increased the contents of total phenolic compounds, flavonoids, and anthocyanins in purple sweet potato (Table 2). Total monomeric anthocyanin and flavonoid contents increased around 13 folds and 5 folds, respectively, while the content of phenolic compounds in steamcooked sweet potato increased around 4 folds after steam -cooking. Steam-cooking of purple sweet potato tubers not only gelatinized starch but also inactivated the polyphenol oxidase (PPO), thus reducing the PPO browning reactions (Nevara et al., 2018). Steam-cooking of purple sweet potato even at the household level for 30 min could increase the availability of the (poly)phenolic compounds readily for consumption.
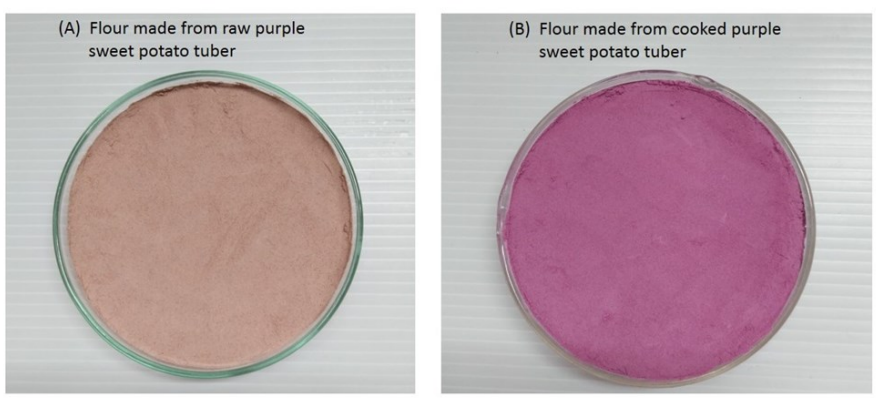

Figure 4. Effect of steam-cooking at household level on the color of purple sweet potato flour from (A) a raw tuber; (B) from a steam-cooked tuber

Phenolic compounds and flavonoids are substrates for PPO during the enzymatic browning reaction, in the presence of $\mathrm{O}_{2}$ (Belitz et al., 2009). Raw purple yam and purple sweet potato tubers showed a similar amount of monomeric anthocyanin, i.e., around $4 \mathrm{mg} \mathrm{C} 3 \mathrm{G} / 100 \mathrm{~g}$ $(P \geq 0.05)$. However, purple sweet potato tubers contained much higher phenolic and flavonoid contents than the KKFCRC yam tubers $(P<0.05)$. The raw purple sweet potato could undergo enzymatic browning during the drying process at $40^{\circ} \mathrm{C}$ for $24 \mathrm{~h}$ to a greater extent than did the purple yam, generating $o$-quinone that polymerized to brown pigment melanin in raw purple sweet potato flour (Figure 4). In contrast, the raw purple yam flour retained the purple color (Figure 1).

In summary, steam-cooking at the household level could help to retain (poly)phenolic compounds in purple yam while making them more available for consumption in purple sweet potato. Nonetheless, the different responses to heat and $\mathrm{O}_{2}$ of (poly)phenolic compounds are, in part, governed by the contents of indigenous phenolic compounds and flavonoids prone to PPO activities. The insights obtained from this study could be used in tailoring the biosynthesis of phenolic compounds and anthocyanins in the colored tuberous plant breeding program in the future.

\section{Conflict of interest}

The authors declare no conflict of interest.

\section{Acknowledgments}

Financial support on graduate student fellowship to author Cakrawati provided by the Department of Food Science and Technology, Faculty Agro-industry, and Kasetsart University is gratefully acknowledged. We are grateful to Siew-Sngiem Karnchanachari Research Leadership Awards from Svita Foundation and Kasetsart University for funding this research.

\section{References}

Belitz, H.D., Grosch, W. and Schieberle, P. (2009). Food Chemistry. Berlin: Springer-Verlag.

Cornago, D.F., Rumbaoa, R.G.O. and Geronimo, phill.M. (2011). Philippine yam (Dioscorea spp.) tubers phenolic content and antioxidant capacity. Philippine Journal of Science, 140(2), 145-152.

Table 2. Effect of steam-cooking at household level on phenolic and polyphenolic compounds in purple sweet potato flour

\begin{tabular}{lcc}
\hline Polyphenolic constituent & Raw sweet potato tuber & Steam-cooked sweet potato tuber \\
\hline Total phenolic content (mg GAE/100 g, d.b.) & $176.11 \pm 24.48^{\mathrm{b}}$ & $691.07 \pm 46.89^{\mathrm{a}}$ \\
Total flavonoid content (mg CE/100 g, d.b.) & $86.28 \pm 14.59^{\mathrm{b}}$ & $463.10 \pm 29.24^{\mathrm{a}}$ \\
Total monomeric anthocyanin (mg C3G/100 g, d.b.) & $4.54 \pm 1.34^{\mathrm{b}}$ & $62.81 \pm 4.11^{\mathrm{a}}$ \\
\hline
\end{tabular}

Values are expressed as mean \pm s.d., $\mathrm{n}=2$ independent trials. Values with different superscript in the same row indicate significant differences $(P<0.05)$ 
Cory, H., Passarelli, S., Szeto J., Tamez, M. and Mattei, J. (2018). The role of polyphenols in human health and food systems: A mini-review. Frontiers in Nutrition, 5, e00087. https://doi.org/10.3389/ fnut.2018.00087

Chen, Y., Xu, Y., Cao, Y., Fang, K., Xia, W. and Jiang, Q. (2017). Combined effect of microwave and steam cooking on phytochemical compounds and antioxidant activity of purple sweet potato. Food Science and Technology Research, 23(2), 193-201. https://doi.org/10.3136/fstr.23.193

Christina, Y.I. and Rifa'i, M. (2014). Bioactivity of purple yam tuber (Dioscorea alata L.) on the level of $\mathrm{CD}^{+}$and $\mathrm{CD}^{+} \mathrm{CD}^{-} 62 \mathrm{~L}^{+} \mathrm{T}$ cells and histology of liver in BALB/c mice model of digestive allergy. Journal of Experimental Life Science, 4(2), 27-33. https://doi.org/10.21776/ub.jels.2014.004.02.01

de Aguiar Cipriano, P., Ekici, L., Barnes, R.C., Gomes, C. and Talcott, S.T. (2015). Pre-heating and polyphenol oxidase inhibition impact on extraction of purple sweet potato anthocyanins. Food Chemistry, 180, 227-234. https://doi.org/10.1016/ j.foodchem.2015.02.020

Dewanto, V., Wu, X., Adom, K.K. and Liu, R.H. (2002). Thermal processing enhances the nutritional value of tomatoes by increasing total antioxidant activity. Journal of Agricultural and Food Chemistry, 50, 3010-3014. https://doi.org/10.1021/jf0115589

Di Majo, D., La Guardia, M., Giammanco, S., La Neve, L. and Giammanco, M. (2008). The antioxidant capacity of red wine in relationship with its polyphenolic constituents. Food Chemistry, 111(1), 45-49.

https://doi.org/10.1016/ j.foodchem.2008.03.037

Huang, D., Boxin, U. and Prior, L.R. (2005). The chemistry behind antioxidant capacity assays. Journal of Agricultural and Food Chemistry, 53, 1841-1846. https://doi.org/10.1021/jf030723c

Hong, K.H. and Koh, E. (2016). Effects of cooking methods on anthocyanins and total phenolics in purple-fleshed sweet potato. Journal of Food Processing and Preservation, 40(5), 1054-1063. https://doi.org/10.1111/jfpp.12686

Imanningsih, N., Muchtadi, D., Wresdiyati, T. and Palupi, N.S. (2013). Acidic soaking and steam blanching retain anthocyanins and polyphenols in purple Dioscorea alata flour. Journal of Food Technology and Industry, 24(2), 121-128. https:// doi.org/10.6066/jtip.2013.24.2.121

Kano, M., Takayanagi, T., Harada, K., Makino, K. and Ishikawa, F. (2005). Antioxidative activity of anthocyanins from purple sweet potato, Ipomoea batatas cultivar Ayamurasaki. Bioscience, Biotechnology and Biochemistry, 69(5), 979-988. https://doi.org/10.1271/bbb.69.979

Lebot, V. (2020). Tropical Root and Tuber Crops: Cassava, Sweet Potato, Yams and Aroids. $2^{\text {nd }}$ ed. Oxfordshire: CABI. https:// doi.org/10.1079/9781789243369.0000

Lee, J., Durst, R.W. and Worlstad, R.E. (2005). Determination of total monomeric anthocyanin pigment content of fruit juices, beverages, natural colorants and wines by the $\mathrm{pH}$ differential method: collaborative study. Journal of AOAC International, 88(5), 1269-1278. https://doi.org/10.1093/ jaoac/88.5.1269

Moriya, C., Hosoya, T., Agawa, S., Sugiyama, Y., Kozone, I., Shin-ya, K., Terahara, N. and Kumazawa, S. (2015). New acylated anthocyanins from purple yam and their antioxidant activity. Bioscience Biotechnology and Biochemistry, 79(9), 1484-1492.

doi.org/10.1080/09168451.2015.1027652

Nevara, G.A., Yea, C.S., Karim, R., Muhammad, K. and Ghazali, H.M. (2018). Effects of moist-heat treatments on color improvement, physicochemical, antioxidant and resistant starch properties of drumdried purple sweet potato powder. Journal of Food Process Engineering, 42(1), e12951. https:// doi.org/10.1111/jfpe. 12951

Re, R., Pellerini, N., Proteggente, A., Pannala, A., Yang, M. and Rice-Evans, C. (1999). Antioxidant activity applying an improved ABTS radical. Free Radical Biology and Medicine, 26(9), 1231-1237. https:// doi.org/10.1016/S0891-5849(98)00315-3

Sadilova, E., Stintzing, F.C. and Carle, R. (2006). Thermal degradation of acylated and non-acylated anthocyanins. Journal of Food Science, 71(8), C504C512. https://doi.org/10.1111/j.17503841.2006.00148.x

Srivichai, S. and Hongsprabhas, P. (2020). Profiling anthocyanins in Thai purple yams (Dioscorea alata L.). International Journal of Food Science, 2020, 1594291. https://doi.org/10.1155/2020/1594291

Steed, L.E. and Truong, V-D. (2008). Anthocyanin content, antioxidant activity and selected physical properties of flowable purple-fleshed sweet potato purees. Journal of Food Science, 73(5), S215-S221. https://doi.org/10.1111/j.1750-3841.2008.00774.x

Truong, V-D., Deighton, N., Thompson, R.T., Mcfeeters, R.F., Dean, L.O., Pecota, K.V. and Yencho, G.C. (2010). Characterization of anthocyanins and anthocyanidins in purple-fleshed sweet potatoes by HPLC-DAD/ESI-MS/MS. Journal of Agricultural 
and Food Chemistry, 58, 404-410. https:// doi.org/10.1021/jf902799a

Tsukui, A. (1988). Stability of anthocyanin pigments of Philippine powdered purple yam - effect of $\mathrm{pH}$, heat, light and oxygen. Journal of Home Economics of Japan, 39(3), 209-215.

Tubaro, F., Ghiselli, A., Rapuzzi, P., Maiorino, M. and Ursini, F. (1998). Analysis of plasma antioxidant capacity by competition kinetics. Free Radical Biology and Medicine, 24(7/8), 1228-1234. https:// doi.org/10.1016/S0891-5849(97)00436-X

Yang, J., Meyers, K.J., Heide, J.V.D. and Liu, R.H. (2004). Varietal differences in phenolic content and antioxidant and antiproliferative activities of onions. Journal of Agricultural and Food Chemistry, 52, 6787-6793. https://doi.org/10.1021/jf0307144

Yoshida, K., Kondo, T., Kameda, K., Kawakishi, S., Lubag, A.J.M., Mendoza, E.M.T. and Goto, T. (1991). Structures of alatanin A, B and C isolated from edible purple yam Dioscorea alata. Tetrahedron Letters, 32(40), 5575-5578. https:// doi.org/10.1016/0040-4039(91)80087-M 